International Journal of Business Management and Economic Review

Vol. 4, No. 04; 2021

ISSN: 2581-4664

\title{
THE EFFECT OF ORGANIZATIONAL COMMITMENT AND PROFESSIONAL COMMITMENT ON EMPLOYEE WORK MOTIVATION AND ITS IMPACT ON PERFORMANCE OF CUT NYAK DHIEN HOSPITAL EMPLOYEES
}

\author{
Teuku Larmanda, Amri and Iskandarsyah \\ Magister Manajemen, UniversitasSyiah Kuala, Indonesia \\ http://doi.org/10.35409/IJBMER.2021.3298
}

\begin{abstract}
This study intends to examine the effect of organizational commitment and professional commitment on work motivation and their impact on employee performance at the Cut NyakDhien General Hospital in Aceh Barat District, Indonesia. The population of this study was all medical and non-medical employees at Cut NyakDhien Hospital, totaling 1773 people. The sampling technique used in this research was proportional stratified random sampling accompanied by the use of the Slovin formula so as to produce a total sample of 326 people. Data were collected using a questionnaire and analyzed using the Structural Equation Modeling (SEM) method. The test results prove that organizational commitment and professional commitment can significantly affect work motivation and employee performance, work motivation can significantly affect the performance of Cut NyakDhien Hospital employees, and work motivation can be a partial mediator on the model of the influence of organizational commitment and professional commitment on the performance of Cut NyakDienHospital employees. The interesting thing is that it is proven that the model of improving employee performance at Cut NyakDhien Hospital can be done by strengthening organizational commitment and professional commitment so that it will be able to directly affect the increase in work motivation, and influence both directly and indirectly the increase in employee performance with work motivation as a mediator. The findings can be used as academic references and future researchers are expected to be able to develop this tested model by adding other moderating variables such as job satisfaction, knowledge management, and knowledge sharing.
\end{abstract}

Keyword: Organizational Commitment, Professional Commitment, Work Motivation, and Employee Performance.

\section{INTRODUCTION}

The hospital is one form of organization in which there are general health services that support health efforts. In other words, the hospital is a community institution which is an instrument of society. Therefore, it is necessary for employees who are able to have commitments in increasing performance potential both for employee performance and the impact on the hospital. The comfort and quality contained in the hospital is strongly influenced by the performance of the employees who work to serve the community in the hospital. 


\section{International Journal of Business Management and Economic Review}

Vol. 4, No. 04; 2021

ISSN: 2581-4664

Efforts to improve a person's performance must be balanced with the motivation of that person. In addition, it is very important for management leaders in an organization to always pay attention to the work motivation of each employee, because if someone does not have the motivation to carry out his work, it will automatically have an effect on the performance produced by the employee. Based on the phenomenon that occurred at the Cut NyakDhien General Hospital located in West Aceh Regency, Indonesia, it is felt that the work motivation of its employees is very low. The low work motivation is caused by a lack of encouragement or stimulation given by the leader. The low work motivation of employees at Cut NyakDhien Hospital can be seen from the quality of services provided to the community/patients who are undergoing treatment at the hospital. Lots of patients complain about the unsatisfactory quality of service provided by all elements in the hospital to them, especially nurses and administrative staff.

Therefore, it is very important for every leader in the organization to try to increase the work motivation of their employees. These efforts must be made extra in order to foster work motivation in each employee. Several steps that must be taken to increase employee work motivation can be done through job appraisals, promotions, and giving rewards to employees who have high performance. Apart from that, in an effort to increase employee work motivation, growing commitment to employees is also a must. Because employees who have a high commitment will definitely have a good impact on the resulting performance.

Commitment in an organization or hospital is very important for every employee because commitment is an attitude and behavior of a person who will grow a person's motivation in pursuing his job(Yusuf \& Sarif, 2018). This illustrates that commitment in the organization can be interpreted as an attitude of loyalty and psychological conditions that bind employees and their companies and workplaces with the aim of improving and achieving previously designed goals for the advancement of the organization.

In addition to organizational commitment, the professional commitment of employees also greatly affects performance. Professional commitment is the level of individual loyalty to his profession as perceived by the individual(Tranggono \& Kartika, 2008).Professional commitment is an employee's professional attitude towards work that has been previously agreed upon, so that commitment is based on employee loyalty to his work. In carrying out their activities in the hospital environment, professional commitment is highly demanded to be possessed by every employee in the hospital environment, starting from doctors, nurses, pharmacists, to administrative staff on duty at the hospital.

\section{LITERATURE STUDY}

\section{Employee Performance}

Performance is defined as the result of an employee's work from a management process. Employee performance is not only influenced by the ability and expertise at work but is also greatly influenced by his work spirit(Bahri \& Zamzam, 2019). Performance is not only seen as a result, but also concerning independence, consistency with organizational values, understanding of issues related to responsibilities, discipline, and good communication(Fattah, 2017); (Salbiyah \& Mahardhika, 2017).Employee performance is the result of an evaluation of the work carried out by employees compared to predetermined criteria(Ardial, 2018).In this research, performance measurement uses indicators as revealed by(Hakim \& Wuryanto, 2014)among 


\section{International Journal of Business Management and Economic Review}

Vol. 4, No. 04; 2021

ISSN: 2581-4664

others: quality of work, quantity of work, ability to work alone, understanding and recognition of work, ability to solve problems.

\section{Work Motivation}

Motivation is the process of giving encouragement to employees so that they can work in line with the given limits in order to achieve organizational goals optimally(Sulistiyani \& Rosidah, 2009). According to(Manullang, 2001)Motivation can be interpreted as giving enthusiasm at work to employees. (Siagian, 2012)revealed that motivation is the driving force that causes an organization member to be willing and willing to use and mobilize his abilities both in terms of expertise and skills and time to carry out various activities that are his responsibility and complete his obligations, in order to achieve the goals and various organizational goals that have been determined. . Motivation can be interpreted as a mover or drive in humans that can cause, direct, and organize behavior(Robbins \& Judge, 2017). Indicators of work motivation according to(Robbins \& Judge, 2017)consists of: (1) Have a desire (2) Understand the rules, (3) Serious in work, (4) Work better, (5) Develop skills, (6) Be persistent in work

\section{Organizational Commitment}

The first important element that every employee must possess to increase the productivity and efficiency of any organization is organizational commitment. Organizational commitment has a progressive effect on any organization. Organizational goals can be achieved easily, when employees are committed to the goals of the organization. Relevant factors in determining organizational commitment are additional income, shares, efficiency, effectiveness and productivity of the organization(Salleh, Zahari, Said, \& Ali, 2016).Organizational commitment is the identification and involvement of someone who is relatively strong in the organization(Utaminingsih, 2014). According to(Novita et al., 2016)organizational commitment consists of three dimensions and nine indicators, namely:

1) Affective commitment, emotional feelings for the organization and belief in its values. The indicators are (1) feeling comfortable, (2) feeling responsible and (3) feeling proud.

2) Continuance commitment, the perceived economic value of staying in an organization when compared to leaving the organization. The indicators are (1) Working regularly, (2) Wanting to keep working and (3) Feeling afraid to leave work.

3) Normative commitment, the obligation to stay in the organization for moral or ethical reasons. The indicators consist of: (1) Has done a lot, (2) Has contributed a lot and (3) Gained loyalty.

\section{Professional Commitment}

Professional commitment is the level of loyalty of an individual to his profession(Yunianto \& Astuti, 2012). Professional commitment is an appropriate concept as part of the career focus dimension of work commitment. Professional commitment can be said as the relative strength of identification (individual) with involvement in one's profession, acceptance of its goals and willingness to exert effort on behalf of that profession(Gill \& Kaur, 2017).According to(Purwaningtias \& Aisyah, 2018)Professional indicators that will be examined in this research consist of: (1) Feeling confident, (2) Accepting every job, (3) Choosing a profession, (4) Providing services, (5) Providing service, (6) Providing comfort, ( 7) Maintaining good name, 
International Journal of Business Management and Economic Review

Vol. 4, No. 04; 2021

ISSN: 2581-4664

(8) Maintaining membership (9) Providing help

\section{Conceptual Framework}

The conceptual framework of this research can be described as follows :

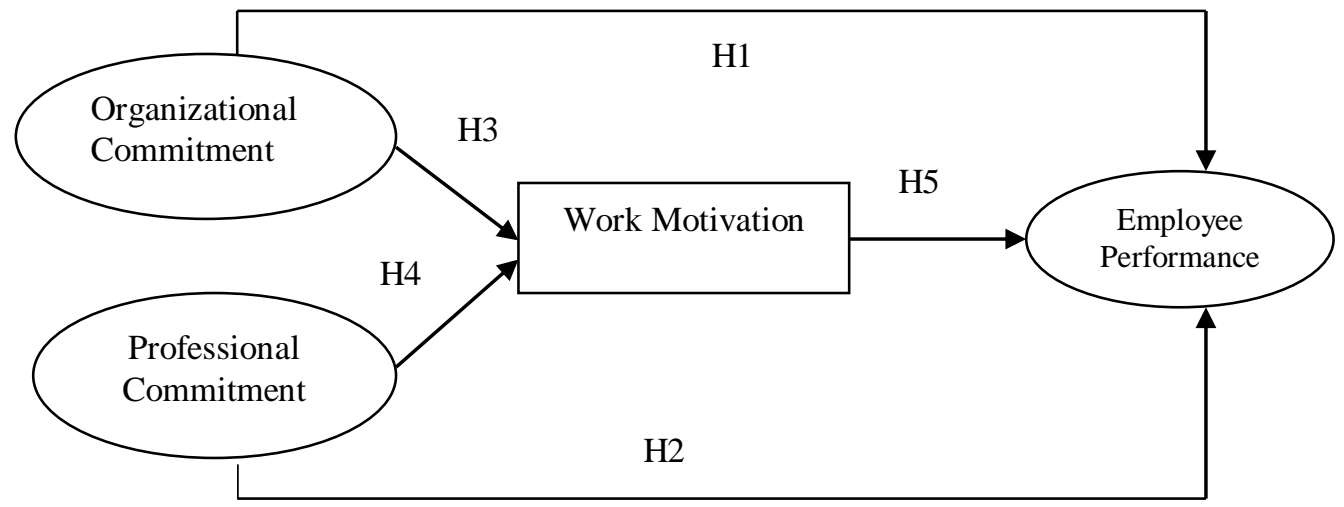

Figure 1. Conceptual Framework

H1: organizational commitment significantly affects employee performance.

H2: professional commitment significantly affects employee performance.

H3: organizational commitment significantly affects employee work motivation.

H4: professional commitment significantly affects employee work motivation

H5: work motivation significantly affects employee performance

H6: organizational commitment significantly affects employee performance through work motivation.

H7: professional commitment significantly affects employee performance through work motivation

\section{RESEARCH METHODS}

This research was conducted at Cut NyakDien Hospital. The objects in this research are organizational commitment, professional commitment, work motivation and performance of employees who work at Cut NyakDhien Hospital located in West Aceh, Indonesia. The research population is all employees, both medical and non-medical employees at Cut NyakDhien Hospital. The details of the data on civil servants (PNS) and honorary workers who work at Cut NyakDhien Hospital can be seen in Table 1 below

Table 1. Civil servant and honorary data

\begin{tabular}{|l|l|l|l|}
\hline No & Personnel & Civil Servant & Honorary \\
\hline 1 & Medical personnel & 29 & 31 \\
\hline 2 & Medical staff & 180 & 887 \\
\hline 2 & Other Health Workers & 73 & 165 \\
\hline 4 & Other Strategic Personnel & 54 & 354 \\
\hline Amount & 336 & 1437 \\
\hline
\end{tabular}


International Journal of Business Management and Economic Review

Vol. 4, No. 04; 2021

ISSN: 2581-4664

\begin{tabular}{|l|l|}
\hline Total & 1773 \\
\hline
\end{tabular}

Source: Cut NyakDhien Hospital (2019)

The sampling technique applied is proportional stratified random sampling. The minimum number of research samples is determined using the Slovin formula, namely:

$$
\begin{aligned}
& \mathrm{n}=\frac{N}{N e^{2}+1} \\
& \mathrm{n}=\frac{1773}{(1773)(0,05)^{2}+1} \\
& \mathrm{n}=\frac{1773}{(1773)(0,05)+1} \\
& \mathrm{n}=\frac{1773}{5,4325} \\
& =326,36, \text { rounded to } 326 .
\end{aligned}
$$

Based on the proportional stratified random sampling method, the total number of samples in this research is shown in table 2 below.

\section{Table 2. Research Sample}

\begin{tabular}{|l|l|l|l|}
\hline No & Personnel & Population & Sample \\
\hline 1 & Medical personnel & 60 & $\frac{60}{1773} \times 326=11$ \\
\hline 2 & Medical staff & 1067 & $\frac{1067}{1773} \times 326=196$ \\
\hline 2 & Other Health Workers & 238 & $\frac{238}{1773} \times 326=44$ \\
\hline 4 & Other Strategic Personnel & 408 & $\frac{408}{1773} \times 326=75$ \\
\hline \multicolumn{2}{|l|}{ Amount } & 1773 & 326 \\
\hline
\end{tabular}

Source: Cut NyakDhien Hospital (2019)

In this research, medical personnel is specialist doctors who work at Cut NyakDhien Hospital. The medical staff is nurses who work at Cut NyakDhien Hospital. Other health workers are pharmacists, psychologists, health analysts, and nutritionists. Meanwhile, other strategic personnel is the administrative staff who work at Cut NyakDhien Hospital.

Data were collected through documentation and questionnaires distributed directly to respondents and measured using a Likert scale. Direct hypothesis testing was analyzed using the Amos SEM application and indirect hypothesis testing was analyzed using a Sobel calculator.

\section{RESULTS}

\section{Direct Effect Test}

The results of the direct test of the effect on the performance model of the Cut NyakDhien Hospital as determined in this research can be seen as follows. 
International Journal of Business Management and Economic Review

Vol. 4, No. 04; 2021

ISSN: 2581-4664

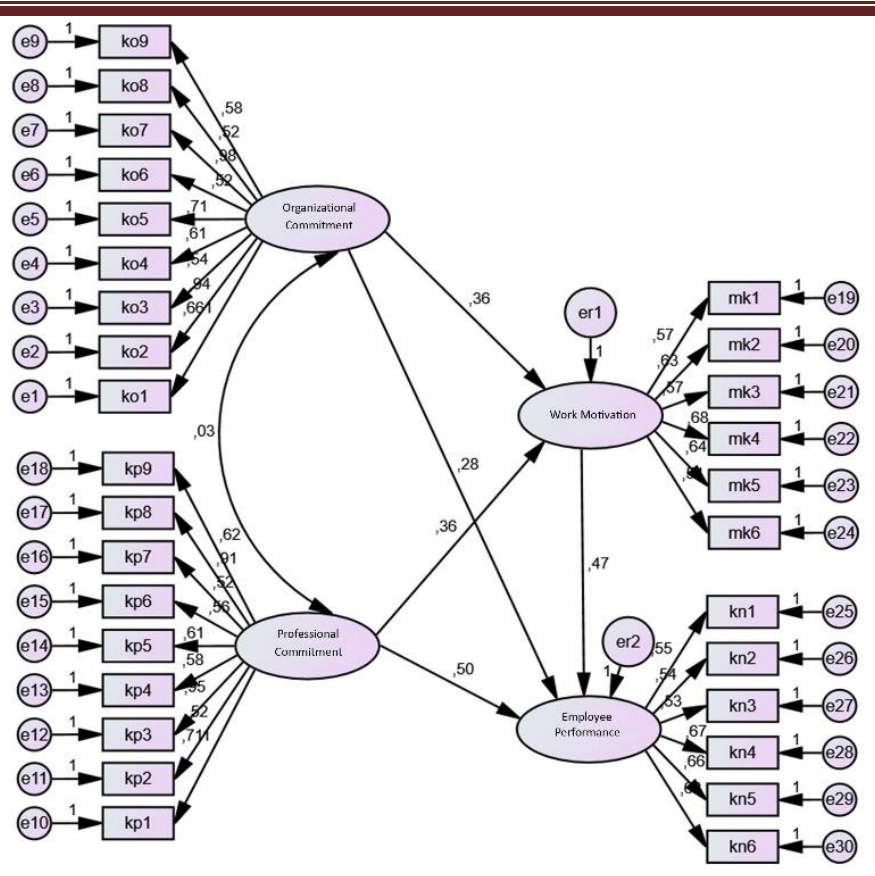

Figure 2. Full SEM Model

The results of testing the full model for hypothesis testing after going through the fulfillment of SEM assumptions are more clearly contained in the following table:

Table 3. Regression Weight Full Model SEM

\begin{tabular}{|l|l|l|l|l|l|}
\hline Endogenous & & Exogenous & Estimate & C.R. & P \\
\hline Work Motivation & $<---$ & Organizational Commitment & 0.249 & 5.415 & $* * *$ \\
\hline Work Motivation & $<---$ & Professional Commitment & 0.161 & 6.824 & $* * *$ \\
\hline Employee Performance & $<---$ & Organizational Commitment & 0.133 & 5.041 & $* * *$ \\
\hline Employee Performance & $<---$ & Professional Commitment & 0.151 & 3.101 & $* * *$ \\
\hline Employee Performance & $<---$ & Work Motivation & 0.323 & 7.375 & $* * *$ \\
\hline
\end{tabular}

Source: Primary Data, 2021 (processed)

From the test results of the type of direct influence according to the table above, it can be seen that:

1. H1: The test results on the effect of organizational commitment on employee performance resulted in a Critical Ratio (CR) value of 5.041 and a probability value (p-value) of 0.000 . This value indicates that the Hypothesis 1 model is sufficient to be accepted, namely the CR value $>1.96$ and followed by a p-value $<0.05$. So it can be proven that organizational commitment significantly affects the performance of Cut NyakDhien Hospital employees. This indicates that the higher the level of organizational commitment of the Cut NyakDhien Hospital employees will have an effect on improving the performance of Cut NyakDhien 
International Journal of Business Management and Economic Review

Vol. 4, No. 04; 2021

ISSN: 2581-4664

Hospital employees, especially in improving the work results of all employees within the organization. The research results are also consistent with the findings of research conducted by(Respatiningsih \& Sudirjo, 2015)which states that partially (individually) there is a significant influence between organizational commitment on employee performance.

2. H2: The test results on the effect of employee professional commitment on employee performance resulted in a CR value of 3.101 and a p-value of 0.000 . This value indicates that the Hypothesis 2 model is sufficient to be accepted, namely the CR value $>1.96$ and followed by a p-value $<0.05$. So it can be proven that the professional commitment of employees felt by all Cut NyakDhien Hospital employees has an influence on improving employee performance, especially in providing services to the community in West Aceh Regency. The results of this research are also consistent with the findings of research conducted by(Waterkamp, Tawas, \& Mintardjo, 2017)which states that every organization must maintain the professional attitude of its employees at work so that employees get satisfaction in their respective jobs in the author's research results above show a significant influence between employee professionalism on job satisfaction in the company. Directly professionalism also has a positive and significant influence on employee performance, this needs to be improved for the company.

3. H3: The test results on the effect of organizational commitment on employee work motivation resulted in a CR value of 5.415 and a p-value of 0.000 . This value indicates that the Hypothesis 3 model is sufficient to be accepted, namely the CR value $>1.96$ and followed by a p-value $<0.05$. So it can be proven that the organizational commitment of Cut NyakDhien Hospital employees has an effect on employee work motivation. This indicates that the better organizational commitment will significantly affect the increase in work motivation of Cut NyakDhien Hospital employees. The results of this research are consistent and in line with the results of previous research conducted by(Arifah \& Romadhon, 2015)that organizational commitment is a combination of attitude and behavior.

4. H4: The test results on the effect of professional commitment on employee work motivation resulted in a CR value of 6.824 and a p-value of 0.000 . This value shows that the Hypothesis 4 model is sufficient to be accepted, namely the CR value $>1.96$ and followed by a p-value $<0.05$. So it can be proven that the professional commitment felt by employees at Cut NyakDhien Hospital significantly affects the work motivation of employees at Cut NyakDhien Hospital. This indicates that the higher the professional commitment felt by the employees, the higher the employee's work motivation. The results of this research are consistent and in line with research conducted by(Arifah \& Romadhon, 2015), who stated that professional commitment will affect one's motivation to work.

5. H5: The test results on the effect of testing the effect of employee work motivation on employee performance resulted in a CR value of 7.375 and a p-value of 0.000 . This value shows that the Hypothesis 4 model is sufficient to be accepted, namely the CR value $>1.96$ and followed by a p-value $<0.05$. So it can be proven that employee work motivation has an effect on employee performance at Cut NyakDhien Hospital. This indicates that the higher the employee's work motivation, the Cut NyakDhien Hospital employees will further improve the employee's performance because each employee will be motivated to achieve better work results. The results of this research are consistent with research conducted by(Tranggono \& Kartika, 2008), that organizational commitment and professional 
Vol. 4, No. 04; 2021

ISSN: 2581-4664

commitment significantly affect auditor job satisfaction, while motivation has a small and insignificant effect on job satisfaction.

Furthermore, the results of indirect hypothesis testing are to test the role of mediation as described below:

1. H6: Testing the effect of organizational commitment on the performance of Cut NyakDhien Hospital employees through work motivation aims to prove whether there is a significant effect on the mediation effect or not. Testing the mediating effect (mediating effect) in this research uses the approach(Baron \& Kenny, 1986). The test results are explained as follows.

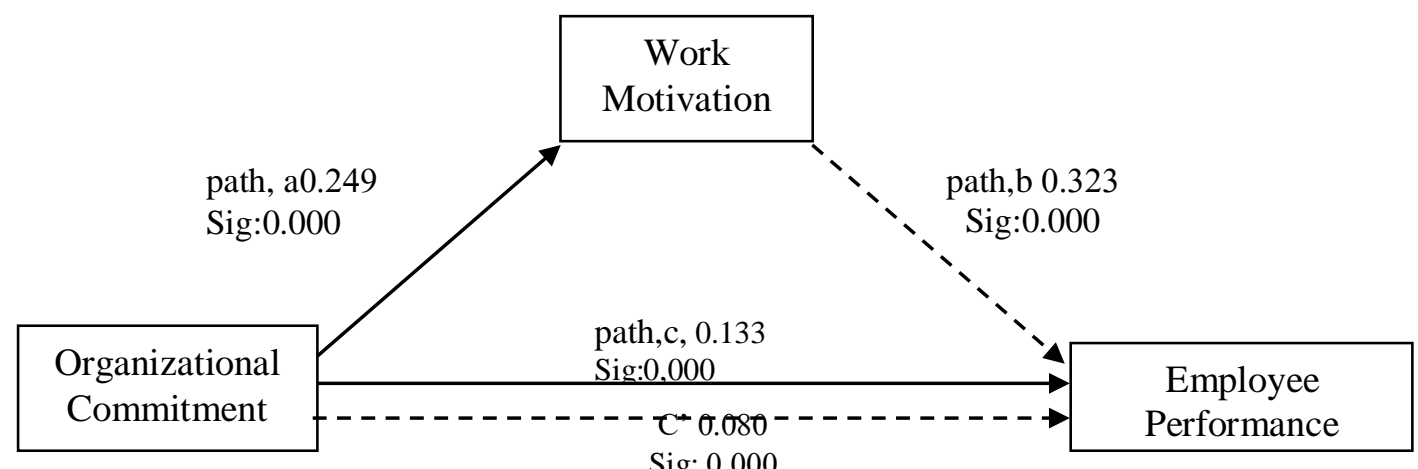

Figure 3. Testing the Mediation Effect of Hypothesis 7

Information:

$$
\begin{aligned}
C^{\prime} & =\text { path } \mathrm{a} \times \text { path } \mathrm{b} \\
& =0.249 \times 0.323 \\
& =0.080
\end{aligned}
$$

Based on the test results above, it can be revealed that organizational commitment significantly affects the performance of Cut Nyak Dhien Hospital employees through work motivation as a mediator. In addition, if you look at the results of the previous direct influence test, the results state that organizational commitment significantly affects work motivation, and work motivation significantly affects the performance of Cut Nyak Dhien Hospital employees. Thus, testing on this model proves that work motivation plays a role in the model as a partial mediator.

2. H7: Testing the effect of professional commitment on the performance of Cut NyakDhien Hospital employees through work motivation as shown below. 


\section{International Journal of Business Management and Economic Review}

Vol. 4, No. 04; 2021

ISSN: 2581-4664

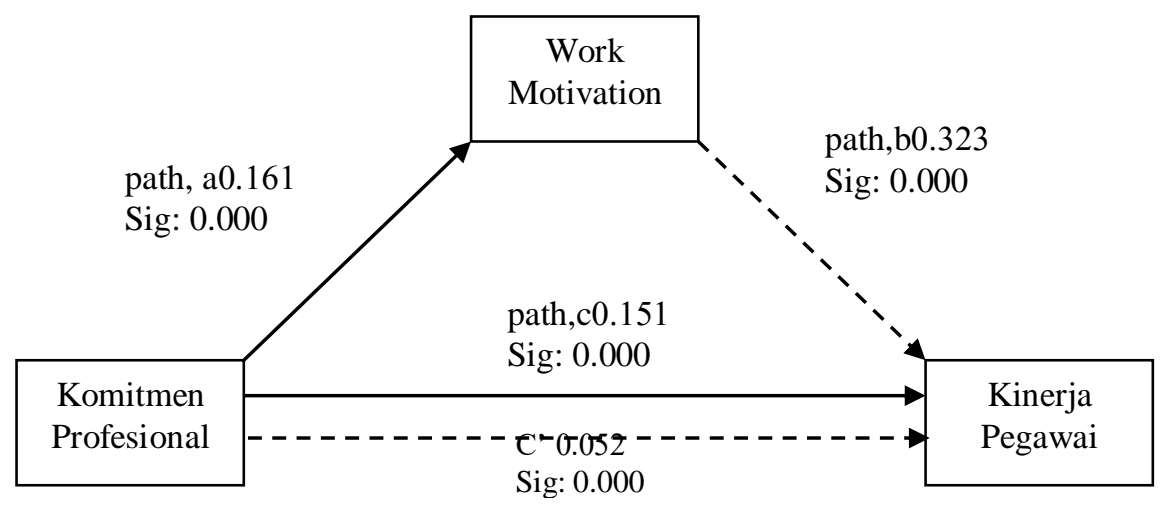

Figure 4. Testing the Mediation Effect of Hypothesis 7

Information:

$\mathrm{C}^{\prime} \quad=$ path $\mathrm{a} \times$ path $\mathrm{b}$

$=0.161 \times 0.323$

$=0.052$

Based on the results of the analysis, it was shown that all exogenous variables had a significant effect on endogenous variables, and no insignificant effect was found so that in this study there was no full mediated. Thus, it can be concluded that the findings in this subsample are consistent with the findings in the entire sample, in which the motivation variable has a role as a partially mediated variable between the professional commitment variable and the performance of the Cut NyakDhien Hospital employees.

\section{CONCLUSION}

The results of research on Cut NyakDhien Hospital employees prove that the results of hypothesis testing have a direct influence, organizational commitment, and professional commitment significantly affect employee work motivation, and organizational commitment, professional commitment, and work motivation significantly affect the performance of Cut NyakDhien Hospital employees. Meanwhile, based on the results of hypothesis testing, the indirect effect proves that work motivation mediates the effect of organizational commitment and professional commitment on the performance of Cut NyakDhien Hospital employees.

The results of this research have an implication that a strong organizational commitment will have an effect on increasing employee work motivation and also increasing employee performance at Cut Nyak Dhien Hospital. An increase in employee work motivation can be seen from an increase both in quality and quantity in motivational improvement programs such as a life insurance program from an organization that makes employees work better, security guarantees that make employees more motivated at work, activities such as leadership providing awards for work achievements that have been obtained by employees, feelings of employees who feel proud to be part of this organization, employees feel that they can always actualize themselves, and also employees feel that what they do for the organization still needs to be 


\section{International Journal of Business Management and Economic Review}

Vol. 4, No. 04; 2021

ISSN: 2581-4664

improved.

The implications of research results on the effect of professional commitment variables on work motivation and employee performance indicate that professional commitment between employees and the organization will have an effect on improving employee performance at Cut NyakDhien Hospital. The results of the research on the influence of professional commitment on employee performance can be seen that employees feel comfortable while working at Cut NyakDhien Hospital, employees feel a sense of responsibility while I work at Cut NyakDhien Hospital and also employees feel proud to be part of employees at Cut NyakDhien Hospital and I want to work regularly, because the salary I get is adequate.

Regarding the implications of the influence of work motivation on employee performance, it is also proven that there is a positive and significant influence, the results of this research have the implication that the presence of high work motivation possessed by employees will have an influence on employee performance planning, this can be seen from the attitude of employees who always try to perform by providing all the capabilities possessed for the benefit of the organization rather than for the interests of groups or groups as well as self-interest. In addition to the work motivation possessed by employees, they will also provide contributions or considerations from the leadership to provide opportunities for these employees to develop their careers for the better.

\section{REFERENCES}

Ardial. (2018). Organizational Communication Function: Case Study on Organizational Communication Function on Employee Performance. Medan: AQLI Institute for Research and Scientific Writing.

Arifah, D. A., \& Romadhon, C. (2015). PEffect of Organizational Commitment, Professional Commitment and Leadership Style on Job Satisfaction with Motivation as an Intervening Variable. Conference In Business, Accounting, And Management (CBAM), 2(1), 357-369.

Bahri, S., \& Zamzam, F. (2019). Apparatus Resource Management (Study at the Department of Public Works of Highways of South Sumatra Region). Yogyakarta: Deepublish.

Baron, R. M., \& Kenny, D. A. (1986). The moderator-mediator variable distinction in social psychological research: Conceptual, strategic, and statistical considerations. Journal of Personality and Social Psychology, 51(6), 1173-1182. https://doi.org/10.1037//00223514.51.6.1173

Fattah, H. (2017). Job Satisfaction \& Employee Performance. Yogyakarta: Elmatera.

Gill, S. P. K., \& Kaur, H. (2017). A study of professional commitment among senior secondary school teachers. International Journal of Advanced Education and Research, 2(4), 253-257.

Hakim, A., \& Wuryanto. (2014). Employee Performance Improvement Model Through the Role of Communication and Motivation and Their Effect on Job Satisfaction. Journal of Economics and Business, 15(2), 1-18. https://doi.org/http://dx.doi.org/10.30659/ekobis.15.2.1-18

Manullang, M. (2001). Personnel Management Edition 3. Yogyakarta: BPEE.

Novita, Sunuharjo, B. S., \& Ruhana, I. (2016). The Effect of Job Satisfaction and Organizational 


\section{International Journal of Business Management and Economic Review}

Vol. 4, No. 04; 2021

ISSN: 2581-4664

Commitment on Employee Performance (Study at PT. Telekomunikasi Indonesia, Tbk Witel South Java, Malang). Journal of Business Administration, 34(1), 38-46.

Purwaningtias, W., \& Aisyah, M. N. (2018). The Effect of Professional Commitment, Organizational Commitment and Job Satisfaction on Whistleblowing Intentions (Study on Hospital Employees in the Special Region of Yogyakarta. PROFITA: Study of Accounting, 6(5), 1-20.

Respatiningsih, I., \& Sudirjo, F. (2015). Pengaruh Komitmen Organisasi, Motivasi, Kapabilitas dan Kepuasaan Kerja Terhadap Kinerja Pegawai (Studi Empirik pada Inspektorat Kabupaten Pemalang. Serat Acitya (Jurnal Ilmiah), 4(3), 56-58.

Robbins, S. P., \& Judge, T. A. (2017). Essential of Organisational Behaviour (14th ed.). New Jersey: Pearson.

Salbiyah, S., \& Mahardhika, B. W. (2017). The Effect of Work Motivation on the Performance of Education Personnel of Muhammadiyah University of Surabaya in 2016. BALANCE: Economic, Business, Management and Accounting Journal, 14(02), 83-105. https://doi.org/http://dx.doi.org/10.30651/blc.v14i02.1280

Salleh, S. M., Zahari, A. S. M., Said, N. S. M., \& Ali, S. R. O. (2016). The Influence of Work Motivation on Organizational Commitment in the Workplace. Journal of Applied Environmental and Biological Sciences, 6(5S), 139-143.

Siagian, S. P. (2012). Motivation Theory and Its Application. Jakarta: Rineka Cipta.

Sulistiyani, A. T., \& Rosidah. (2009). Human Resource Management: Concepts, Theory and Development in the Context of Public Organizations. Yogyakarta: Graha Ilmu.

Tranggono, R. P., \& Kartika, A. (2008). The Effect of Organizational and Professional Commitment on Auditor Job Satisfaction with Motivation as an Intervening Variable. Journal of Business and Economics, 15(1), 80-90.

Utaminingsih, A. (2014). Perilaku Organisasi: Theoretical \& Empirical Studies on Organizational Culture, Leadership Style, Trust and Commitment. Malang: Universitas Brawijaya Press.

Waterkamp, C. I. A., Tawas, H. N., \& Mintardjo, C. . (2017). The Influence of Professionalism, Organizational Commitment and Job Satisfaction on Employee Performance at PT. Bank Rakyat Indonesia (PERSERO) Manado Branch. Emba's Journal, 5(3), 2808-2818. https://doi.org/https://doi.org/10.35794/emba.v5i3.17159

Yunianto, A., \& Astuti, S. D. (2012). The Role of Professional Commitment to Desire to Move Through Organizational Commitment, Motivation and Auditor Job Satisfaction. Stikubank University (Unisbank) Semarang Repository, 1-8.

Yusuf, R. M., \& Sarif, D. (2018). Organizational Commitment: Definition of Influenced and Influenced. Makassar: Nas Media Pustaka. 